\title{
Effect of Veneer Drying Process on Some Technological Properties of Polystyrene Composite Plywood Panels
}

\section{Utjecaj procesa sušenja furnira na tehnološka svojstva kompozitnih uslojenih drvnih ploča vezanih polistirenom}

\author{
Original scientific paper • Izvorni znanstveni rad \\ Received-prispjelo: 24. 9. 2018. \\ Accepted-prihvaćeno: 20. 11. 2019. \\ UDK: $630 * 812.31 ; 630 * 812.71 ; 630 * 832.281 .7 ; 630 * 832.282 ; 630 * 863$ \\ https://doi.org/10.5552/drvind.2019.1844
}

\begin{abstract}
The aim of study was to determine the effect of veneer drying process on some technological properties of polystyrene composite plywood panels. For this reason, 2 mm-thick rotary cut veneers were obtained from beech (Fagus orientalis, Lipsky), Alder (Alnus glutinosa subsp. Barbata) and Scots pine (Pinus sylvestris L.) logs. The veneers obtained from three different wood species were divided into two groups to produce polystyrene composite plywood (PCP) and traditional plywood. While PCP was produced both air dried (at $20{ }^{\circ} \mathrm{C}$ ) and oven dried (at $110^{\circ} \mathrm{C}$ ), the veneer sheets for production of traditional plywood were dried at $110{ }^{\circ} \mathrm{C}$ until reaching $7 \%$ equilibrium moisture content. Two different types of polystyrene with high density $\left(30 \mathrm{~kg} / \mathrm{m}^{3}\right)$ and low density (16 $\left.\mathrm{kg} / \mathrm{m}^{3}\right)$ were used as bonding material for PCP panel production. The urea-formaldehyde adhesive was used as a bonding material for traditional plywood panels. Bonding shear strength, bending strength, modulus of elasticity and density of plywood and polystyrene composite plywood panels were investigated. It was found that the technological properties observed in the study of composite plywood panels manufactured with natural dried veneers gave similar results compared to those of composites produced with technical dried veneers.
\end{abstract}

Keywords: polystyrene composite plywood (PCP), veneer drying, mechanical properties, styrofoam

SAŽETAK • Cilj ovog istraživanja bio je utvrditi utjecaj procesa sušenja furnira na tehnološka svojstva kompozitnih uslojenih drvnih ploča vezanih polistirenom. Ljušteni furniri debljine $2 \mathrm{~mm}$ pripremljeni su od trupaca drva bukve (Fagus orientalis, Lipsky), drva johe (Alnus glutinosa subsp. Barbata) i drva običnog bora (Pinus sylvestris L.). Furniri od tri različite vrste drva podijeljeni su u dvije skupine kako bi se proizvela kompozitna uslojena ploča vezana polistirenom (PCP) i tradicionalna uslojena ploča. Za proizvodnju PCP ploča rabljeni su furniri sušeni na zraku (na $20^{\circ} \mathrm{C}$ ) i u sušioniku (na $110^{\circ} \mathrm{C}$ ), a za proizvodnju tradicionalne uslojene ploče upotrijebljeni su furniri sušeni pri $110^{\circ} \mathrm{C}$ sve do postizanja ravnotežnog sadržaja vode od $7 \%$. Kao vezivo za PCP ploče uporabljene su dvije vrste polistirena - polistiren velike gustoće $\left(30 \mathrm{~kg} / \mathrm{m}^{3}\right)$ i polistiren male gustoće $\left(16 \mathrm{~kg} / \mathrm{m}^{3}\right)$. Za proizvodnju

\footnotetext{
Author is lecturer at Karadeniz Technical University, Arsin Vocational School, Materials and Material Processing Technologies, Trabzon, Turkey. ${ }^{2}$ Authors are research assistant, associate professor and professor at Karadeniz Technical University, Faculty of Forestry, Department of Forest Industry Engineering, Trabzon, Turkey.

Autor je nastavnik Tehničkog sveučilišta Karadeniz, Strukovna škola Arsin, Materijali i tehnologije prerade materijala, Trabzon, Turska. ${ }^{2}$ Autori su istraživač, izvanredni profesor i profesor Tehničkog sveučilišta Karadeniz, Šumarski fakultet, Zavod za inženjerstvo u šumarstvu, Trabzon, Turska.
} 
tradicionalne uslojene ploče kao vezivo je služilo urea-formaldehidno ljepilo. Istraživani su smična čvrstoća lijepljenog spoja, čvrstoća na savijanje, modul elastičnosti te gustoća uslojene i kompozitne uslojene ploče vezane polistirenom. Utvrđeno je da kompozitne uslojene drvne ploče proizvedene od prirodno sušenih furnira imaju slična promatrana tehnološka svojstva kao i kompoziti proizvedeni od tehnički sušenih furnira.

Ključne riječi: kompozitna uslojena ploča vezana polistirenom (PCP), sušenje furnira, mehanička svojstva, stiropor

\section{INTRODUCTION \\ 1. UVOD}

Production of wood-based composites is one of the largest manufacturing businesses worldwide. They are widely used in diverse fields, including windows and door frames, floors and interior panels in cars that contribute to their popularity (Fang et al., 2013). Plywood, as one of the most important wood-based composite panels, has many areas of use (Demirkir et al., 2013). As compared to solid wood, the chief advantages of plywood are that properties along the length of the panel are nearly equal to properties along the width, resulting in greater resistance to splitting, and the form that permits many applications, where large sheets are desirable (Aydin and Colakoglu, 2008). Formaldehyde-based adhesives such as urea- (UF), phenol-and melamine-formaldehyde resins are widely used in the plywood manufacturing industry (Luo et al., 2015). Additionally, formaldehyde is a potential human carcinogen and, because of its high risk level, it is classified differently than most other pollutants (Bohm et al., 2012). Also, in 1995 the International Agency for Research on Cancer (IARC) classified formaldehyde, in terms of human health, as "Possible Carcinogenic Substances" class and the ratio of formaldehyde that can be released from wood-based materials was limited in most of countries (IARC, 2004; Colakoglu, 1993). After this area was investigated comprehensively, in June 2004 IARC removed formaldehyde from "Possible Carcinogenic Substances" class and identified it as directly carcinogenic to humans (Jianying et al., 2010). As a result, an urgent need has arisen for the development of formaldehyde-free wood adhesives. Significant efforts have been made to reduce or replace formaldehyde contents in adhesive formulations. Although some of these new adhesives have already been used in industrial applications, their supply is limited, which may be due to high modification costs or some weak properties, such as low water-resistance (Fang et al., 2013). Therefore, the chemicals and adhesives used for reducing the formaldehyde emission should be cheap and easily accessible. They should also meet the optimum values described in the standards concerning the technological properties of woodbased panels (Colak et al., 2016). The use of polystyrene materials in plywood manufacturing instead of formaldehyde based adhesives is another method. Disposal of a large amount of abandoned polystyrene in the developed countries is a major concern. Polystyrene composite plywood (PCP) can be manufactured without synthetic resins such as urea-formaldehyde or phenol-formaldehyde (Demirkir et al., 2013; Hu et al., 2005). Therefore, PCP manufacturing can be suitable both environmentally and economically. Furthermore, PCP manufacturing process does not need a gluing machine or the preparation of glue mixture. So, the production process has been simplified. Demirkir et al. (2013) stated in their studies that polystyrene wastes could be evaluated in plywood production as a bonding material. However, some revisions should be made in PCP manufacturing process to increase productivity, since no adhesive is used in the process.

Veneer drying is one of the most important steps of plywood manufacturing process. As known, the aim of the drying process is to reduce moisture content of veneers to obtain suitable values for gluing. Before the gluing process, moisture content of all veneers should be below 7 \% (Demirkir et al., 2013; Lutz, 1978). Drying temperature influences both physical and chemical surface properties of veneer and hence also its thermal conductivity characteristics. The PCP manufacturing process may not need drying process, since no adhesives are used in the production. Numerous studies have been carried out for the effects of veneer drying temperatures on bondability of veneer surfaces (Christiansen, 1990; Lehtinen, 1998; Demirkir et al., 2016), surface-inactivation and bond strength relationship (Demirkir et al., 2016; Frihart and Hunt, 2010) and optimum conditions for surface preparation (Demirkir et al., 2016; River et al., 1991). However, there are few studies about the effect of the drying process on the technological properties of polystyrene composite panels. Veneer drying often becomes a production bottleneck because of inefficient equipment and methods (Baldwin, 1995; Aydin and Colakoglu, 2005). The drying process accounts for some $70 \%$ of the thermal energy consumed in plywood production and approximately $60 \%$ of the mill's total energy requirement.

Therefore, it is also important to present the economic effect of veneer drying process on PCP manufacturing. The aim of this study was to determine the effect of veneer drying process on some technological properties of the PCP panel.

\section{MATERIALS AND METHODS 2. MATERIJALI I METODE}

In this experimental study, $2 \mathrm{~mm}$-thick rotary cut veneers with the dimensions of $500 \mathrm{~mm}$ by $500 \mathrm{~mm}$ were obtained from beech (Fagus orientalis, Lipsky), alder (Alnus glutinosa subsp. barbata) and Scots pine (Pinus sylvestris L.) logs. While alder veneers were manufactured from freshly cut logs, beech and Scots pine logs were steamed for $12 \mathrm{~h}$ before veneer production. A rotary peeler with a maximum horizontal holding capacity of $80 \mathrm{~cm}$ was used for veneer manufactur- 


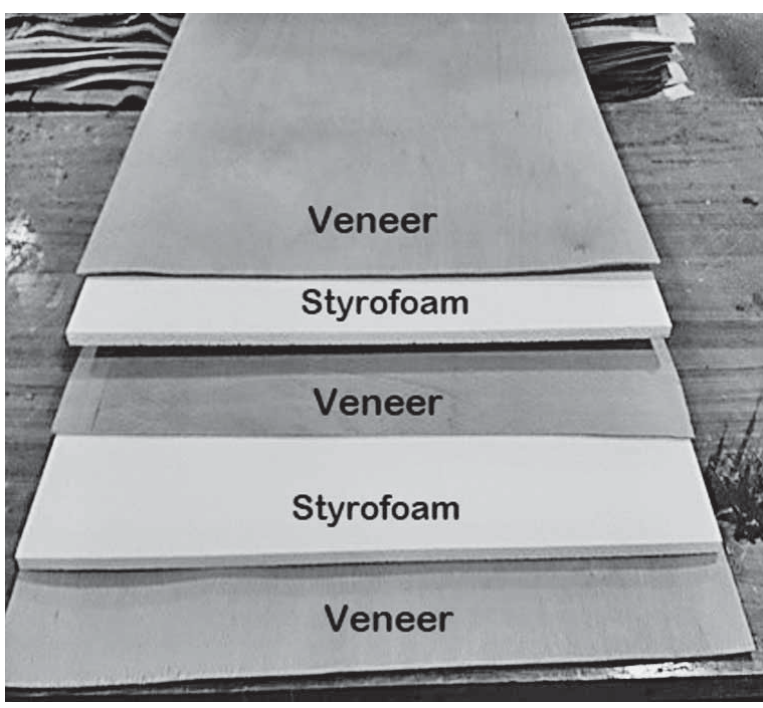

Figure 1 Structural design of three-layer polystyrene composite plywood panels

Slika 1. Konstrukcijski izgled troslojne kompozitne uslojene ploče vezane polistirenom

ing. The horizontal opening between knife and nose bar was $85 \%$ of the veneer thickness, and the vertical opening was $0.5 \mathrm{~mm}$ in the rotary cutting process. The veneers obtained from three different wood species were divided into two groups to produce polystyrene composite plywood and traditional plywood. While PCP was produced both air dried (at $20^{\circ} \mathrm{C}$ ) and oven dried $\left(\right.$ at $110^{\circ} \mathrm{C}$ ), the veneer sheets for production of traditional plywood were dried at $110^{\circ} \mathrm{C}$ until reaching $7 \%$ equilibrium moisture content. The veneers used for PCP panels had a moisture content of 10-12\% (air dried at $20{ }^{\circ} \mathrm{C}$ ) and 5-7\% (at $110{ }^{\circ} \mathrm{C}$ ). After drying, polystyrene composite plywood panel drafts were formed. Polystyrene composite panels were manufactured with 3 layers as shown in Figure 1. The thickness of polystyrene type used in this study was $10 \mathrm{~mm}$. The high density polystyrene (HDP - $30 \mathrm{~kg} / \mathrm{m}^{3}$ ) and low density polystyrene (LDP - $16 \mathrm{~kg} / \mathrm{m}^{3}$ ) were used for PCP panel production. Three-ply-plywood panels, 6 $\mathrm{mm}$ thick, were manufactured from polystyrene as shown in Figure 1. Pressing time and temperature were $8 \mathrm{~min}$ and $150{ }^{\circ} \mathrm{C}$, respectively.

Three-ply-plywood panels, $6 \mathrm{~mm}$ thick, were manufactured by using urea formaldehyde resin. The formulations of adhesive mixture used for traditional plywood manufacturing are given in Table 1 .

The glue mixture was applied at a rate of 160 $\mathrm{g} / \mathrm{m}^{2}$ to a single surface of veneer by using a four-roller glue spreader. Hot press pressure of $12 \mathrm{~kg} / \mathrm{cm}^{2}$ for beech and alder panels and $8 \mathrm{~kg} / \mathrm{cm}^{2}$ for scots pine panels was applied, while hot pressing time and temperature were $6 \mathrm{~min}$ and $110^{\circ} \mathrm{C}$, respectively. Two replicate panels were manufactured for all test groups. Test panels were conditioned at $20{ }^{\circ} \mathrm{C}$ temperature and $65 \%$ relative humidity prior to testing.

Bonding shear strength test was performed according to EN 314-1 standard. Before the bonding shear strength test, samples were immersed for $24 \mathrm{~h}$ in water at $20^{\circ} \mathrm{C}$. Bending strength and modulus of elas-
Table 1 Formulations of UF glue mixture used for manufacturing of plywood

Tablica 1. Formulacija UF ljepila upotrijebljenoga za proizvodnju uslojene ploče

\begin{tabular}{|c|l|c|}
\hline $\begin{array}{c}\text { Glue type } \\
\text { Vrsta ljepila }\end{array}$ & \multicolumn{1}{|c|}{$\begin{array}{c}\text { Ingredients of glue } \\
\text { mixture } \\
\text { Sastojci ljepila }\end{array}$} & $\begin{array}{c}\text { Parts by weight } \\
\text { Težinski udio }\end{array}$ \\
\hline \multirow{5}{*}{$\mathrm{UF}$} & $\begin{array}{l}\text { UF resin (with 55 \% solid } \\
\text { content) / UF smola (s 55 } \\
\text { \% suhe tvari) }\end{array}$ & 100 \\
\cline { 2 - 3 } & $\begin{array}{l}\text { Wheat flour / pšenično } \\
\text { brašno }\end{array}$ & 30 \\
\cline { 2 - 3 } & $\begin{array}{l}\text { Hardener - } \mathrm{NH}_{4} \mathrm{Cl} \\
\text { (with } 15 \% \text { concentration) } \\
\text { otvrdnjivač - } \mathrm{NH}_{4} \mathrm{Cl} \\
\text { (15\%-tne koncentracije) }\end{array}$ & 10 \\
\hline
\end{tabular}

ticity values of panels were evaluated according to EN 310 standard. Density values of the panels were determined according to EN 323 standard. Twenty specimens obtained randomly from the two replicate panels of each group were used for the evaluation of bonding shear strength, bending strength, modulus of elasticity and density.

Multifactor analysis of variance was performed for statistical evaluation of the changes in mechanical properties depending on the wood species, glue types, and number of plies of panels. After ANOVA, StudentNewman-Keuls test was used at $95 \%$ confidence level to compare the mean values of variance sources.

\section{RESULTS AND DISCUSSION} 3. REZULTATI I RASPRAVA

As can be seen from Table 2, the effects of wood species, binder types and veneer drying process on mechanical and physical properties were found statistically significant. Student-Newman-Keuls test was used at $95 \%$ confidence level to compare the mean values of variance sources.

Mean values of bonding strength of PCP panels and traditional plywood panel groups are given in Figure 2.

As can be seen from Table 2, the effect of binder type on the bonding strength of composite panels is significant at $95 \%$ confidence level. As seen from Figure 2 , the bonding strength values of plywood panels manufactured with UF adhesive were found to be the highest. It was also found that the bonding strength values of Polystyrene composite plywood panels with high density Styrofoam were lower than those of composite panels manufactured with low density polystyrene. Demirkir et al. (2013) stated that, since PCP panels produced with low density polystyrene could be pressed easily and homogenously, stronger fastening could be achieved between veneer and polystyrene (Demirkir et al., 2013).

The examination of the effect of wood species on bonding strength of the panels showed that the composite plywood panels manufactured from beech veneers gave the highest bonding strength values. The 
Table 2 Results of Student-Newman-Keuls test at $95 \%$ confidence level for mechanical properties

Tablica 2. Rezultati Student-Newman-Keulsova testa za mehanička svojstva s pouzdanošću od $95 \%$

\begin{tabular}{|c|c|c|c|}
\hline $\begin{array}{l}\text { Properties } \\
\text { Svojstva }\end{array}$ & $\begin{array}{l}\text { Factors } \\
\text { Čimbenici }\end{array}$ & $\begin{array}{c}\text { LS Mean } \\
\text { LS srednja vrijednost }\end{array}$ & \begin{tabular}{|c|} 
Homogenous \\
groups \\
Homogene skupine
\end{tabular} \\
\hline \multirow{11}{*}{$\begin{array}{l}\text { Bonding shear strength } \\
\text { smična čvrstoća } \\
\text { lijepljenog spoja }\end{array}$} & Veneer drying process / Proces sušenja furnira & & \\
\hline & Technical drying / tehničko sušenje & 1.04 & $\mathrm{a}$ \\
\hline & Air dried / prirodno sušenje & 0.88 & $\mathrm{a}$ \\
\hline & Wood species / Vrsta drva & & \\
\hline & Beech / drvo bukve & 1.26 & $\mathrm{a}$ \\
\hline & Alder / drvo johe & 0.85 & $\mathrm{~b}$ \\
\hline & Pine / drvo bora & 0.76 & $\mathrm{c}$ \\
\hline & Binder types / Vrsta veziva & & \\
\hline & HDP & 0.77 & $\mathrm{a}$ \\
\hline & LDP & 1.14 & $\mathrm{~b}$ \\
\hline & UF & 2.09 & $\mathrm{c}$ \\
\hline \multirow{11}{*}{$\begin{array}{l}\text { Bending strength } \\
\text { čvrstoća na savijanje }\end{array}$} & Veneer drying process / Proces sušenja furnira & & \\
\hline & Technical drying / tehničko sušenje & 60.64 & $\mathrm{a}$ \\
\hline & Air dried / prirodno sušenje & 62.25 & $\mathrm{a}$ \\
\hline & Wood species / Vrsta drva & & \\
\hline & Beech / drvo bukve & 89.17 & a \\
\hline & Alder / drvo johe & 56.01 & $\mathrm{~b}$ \\
\hline & Pine / drvo bora & 39.14 & $\mathrm{c}$ \\
\hline & Binder types / Vrsta veziva & & \\
\hline & HDP & 46.90 & $\mathrm{a}$ \\
\hline & LDP & 75.99 & $\mathrm{~b}$ \\
\hline & UF & 83.20 & $\mathrm{~b}$ \\
\hline \multirow{11}{*}{$\begin{array}{l}\text { Modulus of elasticity } \\
\text { modul elastičnosti }\end{array}$} & Veneer drying process / Proces sušenja furnira & & \\
\hline & Technical drying / tehničko sušenje & 5061.26 & $\mathrm{a}$ \\
\hline & Air dried / prirodno sušenje & 5163.27 & $\mathrm{~b}$ \\
\hline & Wood species / Vrsta drva & & \\
\hline & Beech / drvo bukve & 6819.63 & $\mathrm{a}$ \\
\hline & Alder / drvo johe & 4793.14 & $\mathrm{~b}$ \\
\hline & Pine / drvo bora & 3724.03 & $\mathrm{c}$ \\
\hline & Binder types / Vrsta veziva & & \\
\hline & HDP & 4491.77 & $\mathrm{a}$ \\
\hline & LDP & 4793.14 & $\mathrm{~b}$ \\
\hline & UF & 6453.65 & $\mathrm{c}$ \\
\hline \multirow{11}{*}{ Density / Gustoća } & $\begin{array}{l}\text { Veneer drying process } \\
\text { Proces sušenja furnira }\end{array}$ & & \\
\hline & Technical drying / tehničko sušenje & 0.591 & $\mathrm{a}$ \\
\hline & Air dried / prirodno sušenje & 0.604 & $\mathrm{a}$ \\
\hline & Wood species / Vrsta drva & & \\
\hline & Beech / drvo bukve & 0.678 & $\mathrm{a}$ \\
\hline & Alder / drvo johe & 0.586 & $\mathrm{~b}$ \\
\hline & Pine / drvo bora & 0.530 & $\mathrm{c}$ \\
\hline & Binder types / Vrsta veziva & & \\
\hline & HDP & 0.585 & $\mathrm{a}$ \\
\hline & LDP & 0.610 & $\mathrm{~b}$ \\
\hline & UF & 0.636 & $\mathrm{c}$ \\
\hline
\end{tabular}

reason lies in the fact that beech wood has a higher density. It is also known that bonding strength of plywood panels is improved with increasing wood density (Demirkir, 2012).

Bonding strength between wood elements affects all mechanical properties of the wood-based panel products. For maximum adhesive bond strength, the liquid adhesive must wet the wood surface and penetrate into the wood. Adhesive molecules must contact directly with wood molecules to provide the best me- chanical inter locking and inter molecular attraction (Frihart and Hunt, 2010). In the present study, UF adhesive had the best wetting properties among all binding systems used. Therefore, the layers of UF bonded plywood panels may be better bonded to each other in the same production conditions (Demirkir et al., 2013).

Mean values of bending strength of PCP panels and traditional plywood panel groups are given in Figure 3.

The composite panels manufactured with UF adhesive gave the best bending strength values according 


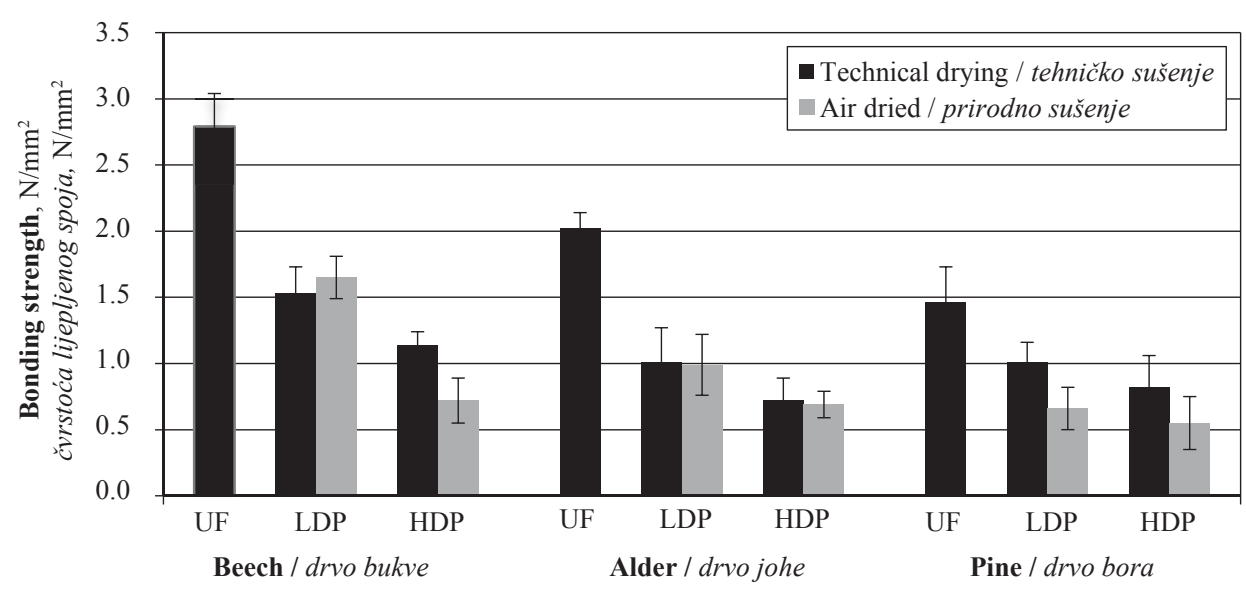

Figure 2 The average bonding strength values of test panels

Slika 2. Srednje vrijednosti čvrstoće lijepljenog spoja ispitivanih ploča

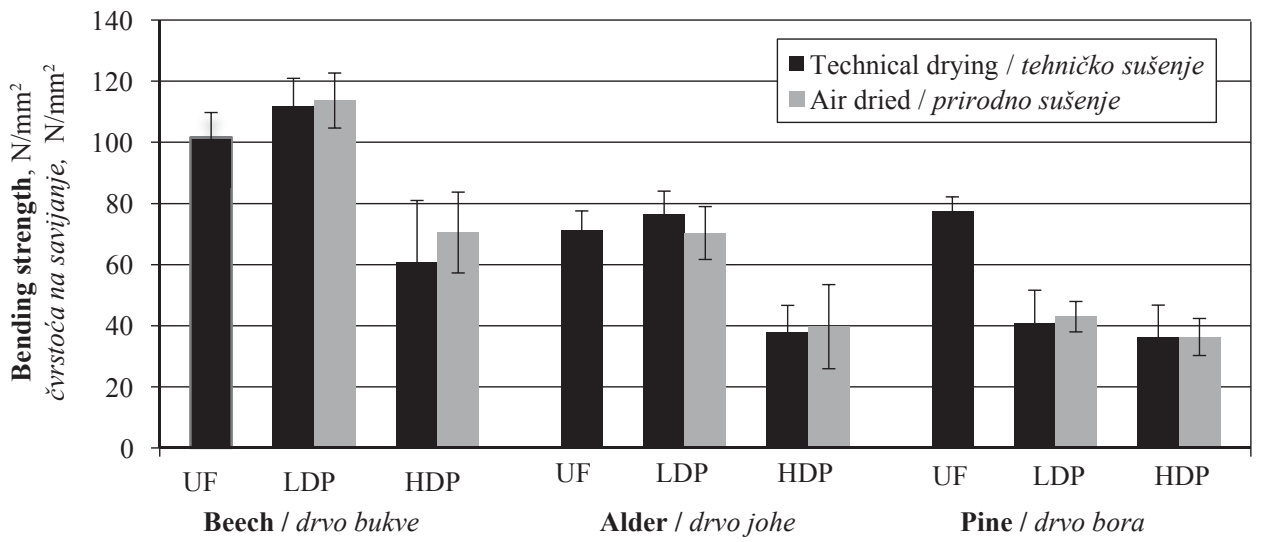

Figure 3 The average bending strength values of test panels

Slika 3. Srednje vrijednosti čvrstoće ispitivanih ploča na savijanje

to statistical analysis in Table 2 . The bending strength values of the composites produced with low density polystyrene were higher than those of the composites with HDP. In literature, it was determined that binder types affected the bending strength values of woodbased composite panels.

When the effect of wood species on the bending strength of the composites was analyzed, the best bending strength values were obtained from beech composite panels. These results were expected because of its higher density among species used in the study. It is known that mechanical properties are improved with increasing density (Wood Handbook, 2010). It was determined that bonding strength values of beech composite plywood panels were the highest in this study. It was stated that a good bonding between wood and adhesive caused the better bending strength (Aydin and Demirkir, 2010). It is expected that a good mechanical bonding will also have a positive effect on bending strength (Demirkir, 2012; Aydin, 2004a). At the same pressing conditions, the glue line of panels manufactured with LDP might be thinner, so the surfaces of plies come closer than those of the panels manufactured with HDP. Therefore, the panels manufactured with LDP will have higher mechanical properties than the panels manufactured with HDP. Kurt and Cil (2012) stated that the glue line thickness directly affects the strength of wood composites and that the press pressure is one of the main factors to control the glue line thickness. They also indicated that one of the most important reasons for the occurrence of a thick glue line is insufficient pressure in the manufacturing process and that, generally, thick glue lines of many common adhesives can cause the strength loss (Kurt and Cil, 2012).

The bending strength values of all composites met the requirements $\left(40 \mathrm{~N} / \mathrm{mm}^{2}\right)$ given in DIN 68705 3 except for some panel groups as seen in Figure 3. Also, the mean values obtained for the bending strength of plywood composite panels were higher than the limit values $(27.4 \mathrm{~N} / \mathrm{mm} 2)$ indicated in Japanese standards (Nanami et al., 2000).

Mean values of modulus of elasticity of PCP panels and traditional plywood panel groups are given in Figure 4.

The effect of binder type on modulus of elasticity was significant at $95 \%$ confidence level. The panels manufactured with UF resin gave the highest modulus of elasticity values. It was shown as Figure 4 the modulus of elasticity values of plywood panels produced with LDP were higher than those of the panels with HDP. It was stated that the effect of adhesive and binder types on the modulus of elasticity of plywood panels was significant (Colak, 2002; Ozturk, 2012; Demir, 2014). In a former study researching some technologi- 


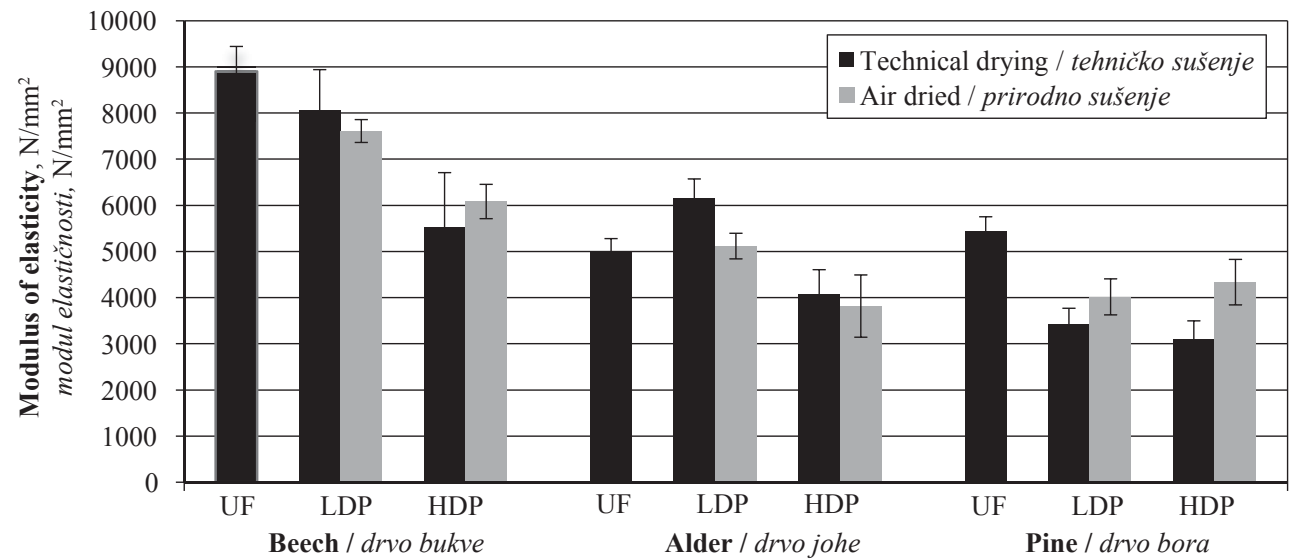

Figure 4 The average modulus of elasticity values of test panels Slika 4. Srednje vrijednosti modula elastičnosti ispitivanih ploča

cal properties of plywood panels manufactured with different polystyrene types, it was found that polystyrene density effected the modulus of elasticity values of the panels (Demirkir et al., 2016). It was also determined that plywood and LVL panels produced with Phenol Formaldehyde resin gave better mechanical characteristics than panels with Melamine Urea Formaldehyde resin (Demirkir, 2012; Tan, 2011).

The highest modulus of elasticity values were obtained from plywood panels manufactured with beech veneer similar to bending strength. In literature, it was indicated that there was an effect of wood species on the modulus of elasticity of plywood. It was also stated that modulus of elasticity values of plywood panels were getting higher with increasing the modulus of elasticity of raw wood used in veneer manufacturing (Demirkir, 2012; Ors et al., 2002).

Mean values of density of PCP panels and traditional plywood panel groups are given in Figure 5.

The highest density values were obtained from the plywood panels bonded with UF resin for both three wood species. The average density values of panels manufactured with HDP were lower than those of panels manufactured with LDP. As the same pressure was applied to all groups, the plywood panels bonded with LDP may become thinner, which results in higher density of the panel (Demirkir et al., 2013). Similar results were found by Demirkir et al. (2013).

The density values of beech plywood panels were higher than those of pine plywood. This effect can be due to the raw materials density, which affects directly the plywood density. Plywood density is mainly dependent on the density of wood species used for the panel production (Rahman et al., 2012). Rahman et al. (2012) and Alam et al. (2012) stated that the difference in density values of plywood panels might depend on the raw material density in the same manufacturing conditions (Rahman et al., 2012; Alam et al., 2012). In addition to the raw material density, the glue type and mixture also contribute to plywood density (River et al., 1991). However, these effects are lower than those of the wood type (Ors et al., 2002).

The green veneers are dried to an average MC that is compatible with the adhesive system used to bond the panels. When veneers are bonded with adhesives to produce plywood, the water in adhesive mixture is absorbed by veneers (Aydin, 2004b). Due to polystyrene, which was used as adhesive with no water content, MC of the veneers did not change in the plywood manufacture. According to statistical analysis, the technical and air-dried processes did not affect the mechanical strength values of panels except the modulus of elasticity.

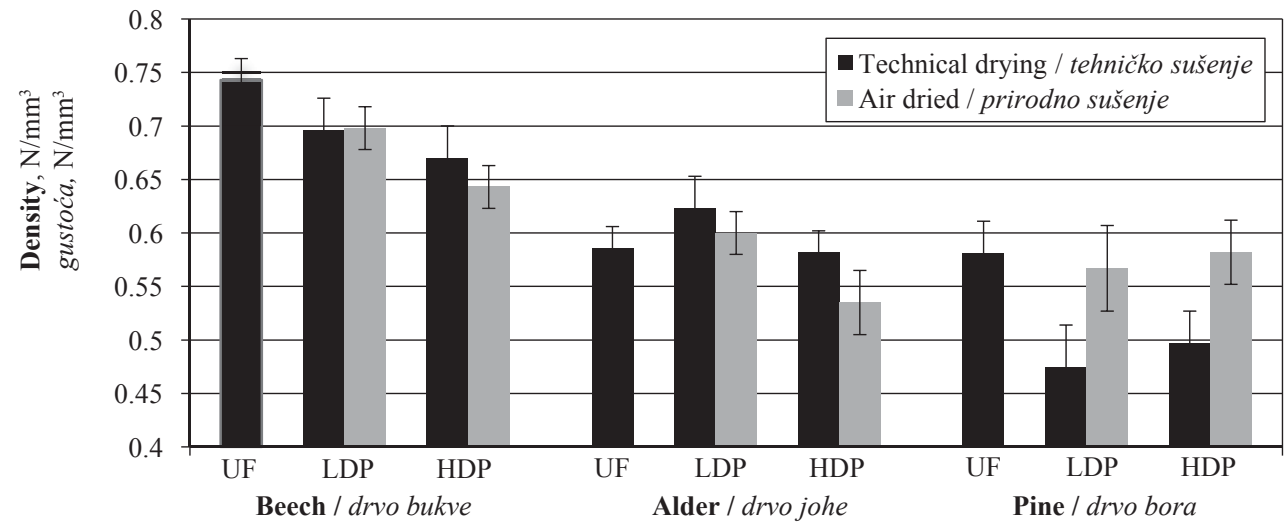

Figure 5 The average density values of test panels Slika 5. Srednje vrijednosti gustoće ispitivanih ploča 


\section{CONCLUSIONS}

\section{ZAKLJUČAK}

In the present study, the technological properties of PCP panels manufactured with air dried veneers and technical dried veneers were generally found similar. $70 \%$ of thermal energy used in plywood manufacturing was used in the veneer drying process. The current study showed that composite plywood panels could be manufactured with HDP and LDP binders without veneer drying process. Considering that the plant's total energy needs are about $60 \%$ (FAO, 1990; Aydin, 2004b), plywood plants could achieve an energy saving of 60 percent.

\section{Acknowledgements - Zahvala}

The authors acknowledge the financial support for this study by TUBITAK (The Scientific and Technical Research Council of Turkey) (Project No: 2140743).

\section{REFERENCES}

\section{LITERATURA}

1. Alam, D. M.; Islam, M. N.; Rahman, K. S.; Alam, M. R., 2012: Comparative study on physical and mechanical properties of plywood produced from eucalyptus (Eucalyptus camaldulensis Dehn.) and simul (Bombax ceiba L.) veneers. Research Journal of Recent Sciences, 1 (9): 54-58. https://doi.org/10.1007/s10086-010-1149-7.

2. Aydin, I., 2004a: Effects of some manufacturing conditions on wettability and bonding of veneers obtained from various wood species. PhD Thesis, KTU Graduate School of Natural and Applied Sciences, Trabzon, Turkey (in Turkish).

3. Aydin, I., 2004b: Surface inactivation in veneer drying process and its effects on bonding strength. Journal of Artvin Forestry Faculty, 1-2: 1-8.

4. Aydin, I.; Colakoglu, G., 2005: Formaldehyde emission, surface roughness, and some properties of plywood as function of veneer drying temperature. Drying Technology, 23 (5): 1107-1117. https://doi.org/10.1081/DRT-200059142.

5. Aydin, I.; Colakoglu, G., 2008: Variations in bending strength and modulus of elasticity of spruce and alder plywood after steaming and high temperature drying. Mechanics of Advanced Materials and Structures, 15: 371-374. https://doi.org/10.1080/15376490801977692.

6. Aydin, I.; Demirkir, C., 2010: Activation of spruce wood surfaces by plasma treatment after long terms of natural surface inactivation. Plasma Chemistry and Plasma Processing, 30: 697-706.

https://doi.org/10.1007/s11090-010-9244-5.

7. Baldwin, R. F., 1995: Veneer drying and preparation. In Plywood and Veneer-Based Products, Chapter 15, Miller Freeman Books: San Francisco.

8. Bohm, M.; Salem, M. Z. M.; Srba, J., 2012: Formaldehyde emission monitoring from a variety of solid wood, plywood, blockboard and flooring products manufactured for building and furnishing materials. Journal of Hazardous Materials, 221-222: 68-79. https://doi.org/68-79. 10.1016/j.jhazmat.2012.04.013.

9. Christiansen, A. W., 1990: How over drying wood reduces its bonding to phenol-formaldehyde adhesives: a critical review of the literature. Part I - physical responses. Wood and Fiber Science, 22: 441-459.
10. Colak, S., 2002: The effect of impregnation procedure at plywood on technological properites, formaldehyde and acid emission of plywood, PhD Thesis. KTU Graduate School of Natural and Applied Sciences, Trabzon, Turkey (in Turkish).

11. Colak, S.; Ozturk, H.; Demir, A., 2016: Some technological properties of plywood produced using with nylon waste as adhesive. İleri Teknoloji Bilimleri Dergisi, 5 (2): 21-27 (in Turkish).

12. Colakoglu, G., 1993: Effect of the production parameter on formaldehyde emission and technical properties of plywood, PhD Thesis. KTU Graduate School of Natural and Applied Sciences, 21 p., Trabzon (in Turkish).

13. Demir, A., 2014: The effects of fire retardant chemicals on thermal conductivity of plywood produced from different wood species, Master Thesis. KTU Graduate School of Natural and Applied Sciences, Trabzon, Turkey (in Turkish).

14. Demirkir, C., 2012: Using possibilities of pine species in Turkey for structural plywood manufacturing, PhD Thesis. KTU Graduate School of Natural and Applied Sciences, Trabzon, Turkey (in Turkish).

15. Demirkir, C.; Colak, S.; Aydin, I., 2013: Some technological properties of wood - Styrofoam composite panels. Composites, Part B: Engineering, 55: 513-517. https://doi.org/10.1016/j.compositesb.2013.07.024.

16. Demirkir, C.; Ozturk, H.; Colakoglu, G., 2016: Some technological properties of polystren composite plywood produced from different density polysytren. 2. International Furniture Congress, 13-15 October. Muğla, Turkey.

17. Fang, L.; Chang, L.; Guo, W.; Ren, Y.; Wang, Z., 2013: Preparation and characterization of wood-plastic plywood bonded with high density polyethylene film. European Journal of Wood and Wood Products, 71: 739-746. https://doi.org/10.1007/s00107-013-0733-0.

18. Frihart, C. R.; Hunt, C. G., 2010: Adhesives with wood materials, bond formation and performance, Wood Handbook - wood as an engineering material. General Technical Report FPL-GTR-190. Madison, WI: U.S. Department of Agriculture, Forest Service, Forest Products Laboratory.

19. Hu, Y.; Nakao, T.; Nakai, T.; Gu, J.; Wang, F., 2005: Vibrational properties of wood plastic plywood. Journal of Wood Science, 51:13-7. https://doi.org/10.1007/s10086-003-0624-9.

20. Jianying, X.; Tao, J.; Yingyan, G.; Min, Z.; Xia, Z., 2010: Reduction of formaldehyde emission of wood-based panels. Bioinformatics and Biomedical Engineering (iCBBE), $20104^{\text {th }}$ International Conference on (18-20 June), 1-3, Chengdu, Chine.

21. Kurt, R.; Cil, M., 2012: Effects of press pressures on glueline thickness and properties of laminated veneer lumber glued with phenol formaldehyde adhesive. BioResources, 7 (49): 5346-5354.

https://doi.org/10.15376/biores.7.3.4341-4349.

22. Lehtinen, M., 1998: Effect of high manufacturing temperatures on mechanical properties of veneers and plywood. International Conference of COST Action E8 Wood Mechanics, May 11-12, Florence, Italia.

23. Luo, J.; Luo, J.; Gao, Q.; Li, J., 2015: Effects of heat treatment on wet shear strength of plywood bonded with soybean meal-based adhesive. Industrial Crops and Products, 63: 281-286. https://doi.org/10.1016/j.indcrop.2014.09.054.

24. Lutz, J. F., 1978: Wood Veneer: Log Selection, Cutting, and Drying, U.S. Department of Agriculture, Technical Bulletin No. 1577. 
25. Nanami, N.; Shibusawa, T.; Sato, M.; Arima, T.; Kawai, M., 2000: Durability assessment of wood-framed walls and mechanical properties of plywood in use. In: Proceedings of the World Conference on Timber Engineering. University of British Columbia.

26. Ors, Y.; Colakoglu, G.; Aydin, I.; Colak, S., 2002: Comparison of some technical properties of plywood produced from beech, okoume and poplar rotary cut veneers in different combinations. Journal of Polytechnic, 5 (3): 257-265.

27. Ozturk, H., 2012: Some technological properties of plywood panels manufactured from alder (Alnus glutinosa subsp. barbata (c.a. mey.) yalt.) species grown in different regions, Master Thesis. KTU Graduate School of Natural and Applied Sciences, Trabzon, Turkey (in Turkish).

28. Rahman, K. S.; Alam, D. M.; Islam, M. N., 2012: Some physical and mechanical properties of bamboo mat-wood veneer plywood. International Research Journal of Biological Sciences, 1 (12): 61-64.

29. River, B. H.; Gillespie, R. H.; Vick, C. B., 1991: Wood as an adherent. In: Minford, J. D. (ed.). Treatise on adhesion and adhesives. New York, NY: Marcel Dekker, Inc. 230 p., vol. 7.

30. Tan, H., 2011: Some technological properties of LVL and plywood produced from logs of spruce and fir growing in distinct regions, $\mathrm{PhD}$ Thesis. KTU Graduate School of Natural and Applied Sciences, Trabzon, Turkey (in Turkish).

31. ***FAO, 1990: Energy Conservation in the Mechanical Forest Industries: FAO Forestry Paper, Food and Agriculture Organization of the United Nations, Rome.
32. ***EN 310, 1993: Wood-based panels. Determination of modulus of elasticity in bending and of bending strength. European Standards, Brussels.

33. ***EN 323, 1993: Wood-Based panels. Determination of density. European Standards, Brussels.

34. ***DIN 68705-3, 2003: Structure Plywood. German Standards Institute, Verlag.

35. ***EN 314-1, 2004: Plywood - Bonding quality. Part 1: Test methods. European Standards, Brussels.

36. ${ }^{* * *}$ IARC, 2004: Overall evaluations on carcinogenicity to humans. In: As evaluated in IARC monographs, vol. 1. Lyon, France: International Agency for Research on Cancer.

37. ***Wood Handbook, 2010: Wood as an engineering material. Madison, Wisconsin: United States Department of Agriculture, Forest Products Laboratory, General Technical Report FPL-GTR-190.

\section{Corresponding address:}

Assoc. Prof. CENK DEMIRKIR, PhD

Karadeniz Technical University

Faculty of Forestry

Department of Forest Industry Engineering

61080 Trabzon, TURKEY

e-mail: cenk@ktu.edu.tr 